\title{
EUTHANASIA IN THE SIDE OF THEOLOGICAL VIEW
}

\author{
David Ming \\ Abdi Gusti Theological Seminary -Nganjuk \\ E-mail: david@sttabdigusti.ac.id
}

\begin{abstract}
Everyone can comment on life and death as the saying written by Goerge Arnold, but that does not mean that everyone can comment on living people being invited to be killed. A person's death is not a human right to determine it but God, the Creator and Protector of the whole nature, including humans who have been planned in the line of life and death. Therefore, when euthanasia arises between the medical and legal circles, then this is not something that can be forced to exist, especially as long as it is discussed without having a strong and clear basis. The author will explain what is Euthanasia ?, the question of Euthanasia's historical problems, the pros and cons of euthanasia, and Euthanasia's theological criticism. The author uses a descriptive method of literature and gets research results as follows: Viewed from the aspect of human rights is a moral breakdown that needs to be evaluated again whether euthanasia is in accordance with human rights values because human rights values essentially deny the existence of euthanasia. Also seen from the religious aspect, euthanasia is never justified. Law 6: "Do not kill" can not be laughed anymore means that refusing euthanasia.
\end{abstract}

Keywords: Euthanasia, Ethict, Theological

\section{INTRODUCTION}

The problem of euthanasia is not solely a problem of medical ethics but the matter of the problem is also bio ethics and is therefore interdisciplinary in nature. Even including legal issues, euthanasia is usually associated with the issue of suicide or suicide. In the Criminal Law, the issue of suicide that needs to be discussed is whether someone who attempted suicide or helped someone else to commit suicide could be convicted, because they were considered to have committed a crime. It also does not stop there, but it involves various other interdisciplinary ethics, social, religious, and so on, so that the problem of euthanasia is truly complex.KUHP Chapter 2 article 344 reads: "Anyone who takes the life of another person at his own request, which is clearly stated with sincerity, is threatened with imprisonment for a maximum of twelve years." ${ }^{1}$ Then 
another problem arises of the Indonesian Medical Ethics Code, a small part also states that doctors are not allowed to abort the womb (abortion provocatus) and end the life of a patient, who according to science and experience is unlikely to recover (euthanasia). $^{2}$

Until recently there was a case of "Tilly Hutapea Rampen". ${ }^{3}$, a doctorate doctorate from Airlangga University of Surabaya who had been hanging for ten years without being tested. The story begins when the dissertation was submitted, Tilly wrote euthanasia. ${ }^{4}$ and Tilly agreed to the practice of euthanasia by injection. The promoter, Prof. Dr. Sahetapy. ${ }^{5}$ did not agree with Tilly's opinion, so Sahetapy resigned and his promoter. As a result of this attitude, Tilly's dissertation has remained uncertain until now. Although the Chancellor of Airlangga has agreed to be tested, but no one dares to continue (testing it) including the Chair of the program. . ${ }^{6}$ So, it turns out a person's attitude towards the issue of euthanasia is very important and can affect his academic career or profession. So, how far is euthanasia? Is the positive impact of euthanasia negative?

This project paper aims to see what exactly euhanasia is? What is the history of euthanasia so that euthanasia thought can emerge? What about the pro and anti euthanasia debates? And finally, the author tries to contribute in ethical and theological thinking to euthanasia. .

\section{WHAT IS EUTHANASIA?}

Euthanasia comes from two Greek words "eu" and "thanatos", meaning "good death" or "gentle death". The closest English term is "Mercy Killing"8 despite the word "killing". Euthanasia comes from the philosophy of the world that is willing to accept good deeds that are bad, by saying that bad deeds can change radically so that it becomes good, due to good motivation and goals.

This kind of thinking comes from the New Moral and Situation Ethics which says that goals and motivations determine the merits of actions. ${ }^{9}$. According to Situation Ethics: "Good and bad don't have absolute rules. Good and bad depend solely on one's motivation and love. "

Euthanasia is one of the results of the New Moral and Situation Ethics. ${ }^{10}$ The situation at that time arose a dilemma: did a doctor have the legal right to end one's life at the request of the patient himself or from his family, with the pretext of relieving or ending the prolonged suffering, without the doctor himself facing legal consequences. In this case the doctor faces a legal conflict. 
As an ordinary person, the doctor did not have the heart to refuse requests from patients and their families. Moreover, the condition of the patient who had been dying for months and the doctor knew that the treatment he had been giving had no potential anymore. Said to be dead, the patient is still breathing, even if "artificially".. ${ }^{11}$ On the other hand, if the doctor fulfills the request of the patient and or his family then the doctor has broken the oath and law. Because through his help, for example by revoking the "respirator", he has ended the life of a sufferer, moreover someone has been entrusted to him to always be guarded about his life. In addition, he had broken the doctor's oath he had spoken before he went into the profession as a doctor. ${ }^{12}$

Euthanasia is divided into three types, as follows. ${ }^{13}$ :

1. Help someone so that his death without suffering. The goal is to alleviate the suffering of the patient, until the patient dies without pain.

2. Accelerate the death of someone who is already sick with the reasons: First, his life is no longer useful: disabled, crazy, seriously ill, and so on. Second, it is a burden for others. Third, there are already too many inhabitants in the world. Fourth, the person is of race or like other nationalities. Fifth, that person has a different ideology, even against society. Sixth, bad people.

3. Mercy-killing: subtle killings at the request of the patient himself, the request of the family or the state.

Another opinion says that euthanasia is divided into two, namely: First, active euthanasia is used to designate cases where the patient has actively ended his life, for example by lethal injection (lethal injection). Second, passive euthanasia is used to refer to cases where the patient is not turned off but left to die.

While the expansion of active and passive euthanasia, voluntary, nonvoluntary and involuntary euthanasia appears. Voluntary euthanasia arises when a patient requests a request to die more quickly. Non-voluntary euthanasia arises when the patient is unable to make an assessment or voice a desire on this issue, and therefore does not express any desire, for example in a coma. In this case the family can take over the decision. Finally involuntary euthanasia arises when the patient reveals that he does not want to die, but is turned off or left to die by another party.

\section{EUTHANASIA HISTORY QUESTIONS}

"... the innocent and the righteous ye shall not slay; for I will not justify the wicked" 
(Ex. 23: 7b).The Hebrew phrase here translated "innocent" means "imbecile [hypocritical, hypocrite], dumb, weak indian". Because it was common for nations around ancient Israel to kill those with disabilities by strangling them. But the God of Israel is also the God of the spirits of his people.

Sparta law also demands that all infants be killed. It is viewed as better than a life that is not happy for them or for their parents. Infanticide killings not only occur in Sparta, but also in Athens.

Phitagoras, Plato and Aristotle rejected suicidal acts in order to avoid heavy life or to avoid duty to themselves and the country, but all three considered it unreasonable to adopt euthanasia.

In the days of Adolf Hitler issued a decree that all "useless lives", namely those with disabilities, were destroyed. Hitler decided for himself what was good and what was not worth, and ordered that all that he thought to be worthless was destroyed.

A Nazi organization called the Reichsarbeitgemenschaft Heil und Pflegeanstalten or RAG, a Reich working group for housing and treatment, worked on Berlin's Tiegarten 4 Road. Their patients are called "euthanasia detainees," because they are designed to carry out a large-scale homicide program with medical attention and actions. In addition, the Nazis also practiced euthanasia on homosexuals in concentration camps of around 500,000 casualties, as well as the extermination of the Gypsies of about 200,000 to 600,000 casualties. Of course euthanasia applied is involuntary euthanasia (the patient does not want to die, but euthanasia does).

This euthanasia case started to get the world's attention when dr. E.M. Pathy is authorized by the patient for euthanasia. The elderly patient, Oscar Aged, is in a state of torture because of his incurable illness. Doctors say the patient will have his death due to an illness. It wasn't long before her organs became worse and no longer functioning. Then, the patient begged the doctor to end his life. But, the problem is, does the doctor have the legal right to end the life of an incurable patient? Until an international conference, August 22-23, 1977 [in order to open a World Legal Conference] in Manila, Philippines, bringing judges from the Philippines, Zambia, Pakistan, Muangthai, Canada, Senegal, Tanzania, India, Bangladesh, Iraq, Israel, The Soviet Union, finally concluded: "the law does not recognize human rights to die."

The World Peace Through Law Center, hosted by the World Peace Through Law Center in Manila, was attended by a number of legal and medical leaders from around the world to discuss euthanasia, but 
still results like the Supreme Court are hard to find. to accept euthanasia. However, there are already signs that legal and medical professionals are starting to fight euthanasia in their respective professions.

English (Scotland): Euthanasia is illegal. However, in 1993 and 1994 the court granted physicians the right to terminate the life of an artificially retained person. In June 1996 a patient in Scotland was "allowed to die."

Michigan (USA): US federal law prohibits euthanasia. In November 1998, voters in the state of Michigan opposed the legalization of "suicide by aid" in one referendum.

Oregon (USA): Oregon is the only U.S. state to legalize euthanasia in 1994 for terminally ill patients and to formally request it. However, as a court has ruled against its enforcement, there is no practice of euthanasia.

New York (USA): In April 1996, a New York-based appeals court, having jurisdiction over the states of Vermont and Connecticut, approved euthanasia.

Colombia: Constitutional court approved euthanasia practice in May 1997 for terminally ill patients who explicitly requested it.

Australia: The first law on euthanasia in the world was passed by parliament in the Northern Territory in 1966. However, the
Australian government issued the repeal of the Act eight months later.

China: In 1998, the government allowed hospitals to practice euthanasia for people in the dying phase, if they requested it.

Denmark: Inpatient patients decide when their vital care is discontinued. Since October 1, 1992, sick patients have died Sweden: assisting suicide is "an offense for which a doctor can not, in extreme cases, uproot a life support machine.

France: Euthanasia is illegal. But, the law distinguishes between active euthanasia - the act of intentionally causing death and regarded as murder - seen as a refusal to prolong the patient's medical function.

Netherlands: On April 10, 2001, the Netherlands became the first country in the world to legalize the Right to Death (euthanasia) after the Dutch Senate approved its draft law amidst the protest reaction of thousands of Dutch citizens in front of the Dutch Senate Building in The Hague. The 75 Senate seats produced 46-28 votes in favor of the promulgation of the Right to Death, which had actually been rejected in the past two decades. One senate member was not present at the vote. So doctors who practice euthanasia are not prosecuted if they fulfill a patient's request to die.

The requirements to carry out euthanasia are endorsed by the Dutch 
Journal Kerugma

E-ISSN: 2622-1039

P-ISSN: 2621-8038

Parliament that a doctor who will euthanasia

or help someone commit suicide must qualify as eligible:

1. The doctor believes that the patient submitted the request voluntarily and has considered it carefully.

2. The doctor believes that the suffering of the patient is unbearable, and there is no prospect of health improvement.

3. The doctor must inform the patient about the patient's condition and prospects.

4. The doctor comes to the conclusion together with the patient that there are no reasonable alternatives related to the patient's situation.

5. The doctor has consulted with at least one other person, an independent doctor, who has studied the patient's condition and provided written opinion about the criteria of care needed.

6. The doctor stops the patient's life or provides rocks for suicide by action and medical attention.

Children aged 12-16 years are also possible to end their lives voluntarily through euthanasia, but must with parental consent. Other parties' permission is not needed for those who are over 16 years old. The final permit to implement euthanasia is issued by Regional Health Committees that have existed in each region and have carried out this task since 1996, when euthanasia actions began to be accepted by the public.
And euthanasia offenders who do not comply with existing regulations could face up to 12 years in prison.

The Dutch government believes that legalizing the Right to Death will reflect the entire opaque content of the law, which leaves the possibility of being open to sue in court if it does not follow strict rules.

\section{PRO AND ANTI EUTHANASIA}

It turns out that euthanasia is a fairly complex problem, so it cannot be seen from the legal and medical aspects alone, but many aspects play a role in the eutahansia decision.

Margaret Tighe, Chair of the NGO Right to Life, said, "I cannot understand the Dutch [85\% of Dutch people agree with the Euthanasia Law]. I really can't understand. I am sure, in the history book that will be written, we will look back with sadness and anger at what the Dutch have done, because euthanasia (voluntarily) is a slippery slope.

" However, what Tighe complained of, contrasted with the British Humanist Association and the Voluntary Euthanasia Society. Both of these groups agree not even just to agree but they are the pioneers promoting (looking for supporters) proeuthanasia society.

The British Humanist Association said:Humanists are sympathetic to voluntary euthanasia. By this we mean 
helping people to die painlessly if their lives have become hopeless, with no prospect of relief before death; ang if they wish to die. Both of these conditions must be rigidly adhered to.

And from the Voluntary Euthanasia Society:The main objectives of the Society are to secure the enactment of the 1969 Voluntary Euthanasia Bill by Parliament. This would authorize doctors to give euthanasia patients when they wish it, provided: (a) the patient has signed an appropriate declaration at least 30 days previously; (b) two doctors, one of cpnsultant status, have certified in writing that the patient is suffering from an incurable condition likely to cause him or her severe distress or to be incapable of rational existence.

\section{From the Patient's Angle}

Pro Euthanasia said that first, if the patient's condition was comatose, breathing daily with artificial lungs and eating by infusion: could such an existence be human? Is not what gives meaning and dignity to our existence is precisely our awareness and responses? Moreover, doctors have said there is no hope, then just dieuthanasia. Second, the family cannot afford to pay for what the patient needs the more the patient is in the hospital, the greater the costs.

Anti Euthanasia said that the patient was actually

experiencing

extreme

psychological distress. Not just the patient, maybe, his family also feels tortured to see the patient suffering constantly. In the end, the patient is deuthanasia, but who can guarantee the reaction of the family left behind 3-4 months after they were abandoned by their lovers? Who dares to guarantee that they will escape the great psychological shocks caused by guilt: "We killed him, he died because of us, we have become killers, woe to us."

\section{From the Corner of Medical Personnel}

Pro Euthanasia said that the purpose of using euthanasia facilities was to spark compassion practically. There is no need to explain that medical staff certainly understand and share the pain of a patient, often the patient's suffering is very difficult to withstand even though pain medication has been given, so motivated by compassion, they begin to think seriously about euthanasia.

Anti Euthanasia said that students of the Faculty of Medicine studied medicine for approximately 7-9 years, with the aim of preserving the life of a patient, not to revoke it. To restore freshness and health, not to facilitate his funeral. So, in other words, a doctor must not break the oath of office - he must be loyal to his oath. Dorothy Marx sees the danger of deciding a patient's death, 
because: first, the doctor decides something with the limitations of his human ability, while the decision requires God's omniscient knowledge. Second, a doctor does not always have a correct prognosis, his estimates are not always correct about the patient's condition. A doctor can do wrong. Third, a doctor does not know God's plan for his patient. Does God want to miraculously heal him by means of a miracle, for the sake and for some of God's own purposes? Who are we, so we want to interfere with God's wise and wonderful plan?

\section{From the Legal Angle}

Pro Euthanasia like Bichon van Ysselmonde and Lombrosso, Garofalo said euthanasia was felt to be more practical, the cost was mild, more certain than having to suffer for long.

Anti Euthanasia such as Moderman, Becaria, Voltaire, Roeslan Saleh, Sahetapy basically said the problem of life and death was determined by His creator, God Almighty.

\section{From the Corner of Religion}

Pro Euthanasia uses John 15:13 as his rationale by saying: "There is no greater love than the love of one who gives his life for his friends." So, if the coma has to sacrifice his life because he does not want to burden his family - maybe a matter of cost or a matter of time that must wait for him then euthanasia is a biblical way.

Anti Euthanasia gives the following rejection: first, the Bible never prioritizes physical life, but spiritual life. For the sake of the soul that must be saved, sometimes our rough body must be sacrificed. Even so the body must be nurtured with full responsibility, but our mortal body is not the same price as our immortal soul. Second, the right to determine the time of death is the Creator who has given lives to humans. Third, God can communicate with people who are no longer able to communicate with other people or receive communication. Maybe we judge the person's existence "under human dignity", but he still reacts to God. Fourth, the implementation of euthanasia sparked the peak of human rebellion - perhaps unnoticed. The implementation of euthanasia does not contain the characteristics of faith. In implementing euthanasia, goodness, wisdom, love, the power of God and so on, everything seems to be denied and doubted. Kars Veling, a member of the Senate from the United Christian Party in the Netherlands, admitted that religious circles did not approve the eutahansia law. Euthanasia is not something that is forced on people, but is only an option, a last resort, for those who have no medical life expectancy anymore. 
Catholic teaching does not agree. Al Budyapranata pr believes that he disagrees with eutahansia for the following reasons: first, that human life has the power of God himself. Second, humans have meaning and value only from God himself. Human value is not the result of people's views, it does not depend on achievement (results) or usefulness. Third, we must not judge the fate of others but on the contrary, it is solider and loves the weak and needs protection. Fourth, endanger others because of negligence. This murder is always unintentional, but in fact can be avoided if the cause is aware of his actions, for example: a doctor who gives drugs inconsequentially.

Islamic teachings also forbid eutahansia. Hadith of the Prophet Muhammad s.a.w. narrated by Annas r.a., as follows:

"That the Messenger of Allah had said: let not each one of you beg for death, because of the hardship that holds it. If it is really necessary for him to do so, then say the following prayer: O Allah! Extend my age, if life is better for me, and kill me when death is better for me. "

Surat An Nisa 'verse 29, Al An'aam verse 151, Surat Al Isra' verse 31, and Surat Al A'raf verse 34 also emphasize the prohibition on euthanasia. For example Surat An Nisa 'verse 29:
O ye who believe. Do not eat your neighbor's property by cheating. Except by the way of trade that applies voluntarily between you. And do not kill yourself. Verily Allah is Most Merciful to you. "

\section{THETHICAL AND THEOLOGICAL CRITICISM}

\section{Ethical Christian Review}

Universal Declaration of Human Rights, article 3, states: "Everyone has the right to live, liberty and the security of person". This article states that a person has "the rights to life", "liberty" and "the security of person". Regarding the right to life or "the right to life" hereinafter in "The International Covenant on Civil and Political Rights" which took effect effectively from March 23, 1976, in Part III Art. 6 (1), states that: "Every human being has the inherent right to life. This right shall be protected by law. No one shall be arbitrarily deprived of his life ".

Furthermore, in Part III art. 7 stated as follows: "No one shall be subjected to torture or to cruel in human or degrading treatment or punishment. Inparticular, no one shall be subjected without his free consent to medical or scientific experimentation. "

As a follow-up, in May 1970, The World Health Assembly decided that "The right to 
health is a fundamental human right." So in the UN declaration on human rights, what is clearly recognized is only the right to life. According to Djoko Prakoso that these human rights are only moral rights and are not yet positive rights, which can be prosecuted both inside and outside the court.

Righteous life is a true moral standard for human existence in carrying out his life. Right needs to be interpreted in: (1) as it is (should be); right; not wrong; (2) not biased; fair; (3) can be trusted (matches the real situation); legitimate; Do not lie; true.

So when examined more deeply in the meaning of "righteous life", live according to what it is or match the real conditions; a true life is not a life of being lied to is a thought that has firmly rejected the presence of euthanasia. The right life allows human existence to live accordingly. If a human being has an obstacle in his physical disability or perhaps his mental disability, or illness in a coma, then the existence of life as it is will allow the human to complete his existence until he is actually declared dead. And that death is legitimate, is not a lie or is said to be a true death that does not have to be controlled to die quickly. Even RI Law No. 39 of 1999 concerning Human Rights article 9 says: "Everyone has the right to live, maintain life and improve their standard of living." So, right living, as it is, needs to be maintained is the right of every human being. Of course these values reject euthanasia.

This rationale is part of the ethical thinking that euthanasia is very contrary to the values of "the right to life" which has been the basis of human rights values. So what are the reasons if a country has approved euthanasia laws like the Netherlands, then that country has violated human rights values. So, it is not surprising that many figures criticize the cynical history of the Cheese country.

Edeltraut Gatteres, a spokesman for the European Parliament said that the law [euthanasia which was passed by the Dutch] was contrary to the European convention on human rights. In Article Two [human rights values], for example, death cannot be imposed on someone intentionally, including those who are deadly or dying. However, the law still opens the possibility for doctors to be tried if they do not meet strict rules. As a result, Gatteres strongly rejects the existence of euthanasia that is contrary to human rights values.

\section{Theological Christian Review}

The theological attitude is very clear in the 6th law: "do not kill" (Exod. 20:13) and confirmed in Deut. 5:17, Rom. 13: 9; James $2: 11$. Clearly, it refers to an act of murder that is being grafted: killing a person, group, 
or self.

In the Bible the verb "to kill" commits an act of murder appears about 14 times, as the word "kill" (dead killed; killed killed) about 130 times, while as a noun (also as a subject) with the word "murder" about 16 times. Thus, even though the number of acts of murder is less than that of being killed or killed, the command "do not kill" is a nonnegotiable fixed price that anyone who violates these values is a rebel of God's will. So in Matthew 5: 7 it says, "Blessed are those who are generous, because they will have mercy." Where is this verse God asks us, so that we also heed and love the lives of people, including those who are mentally handicapped. Verkuyl emphasized that not killing does not mean killing only healthy people but also people with mental disabilities.

So in Matthew 5: 7 it says, "Blessed are those who are generous, because they will have mercy." Where is this verse God asks us, so that we also heed and love the lives of people, including those who are mentally handicapped. Verkuyl emphasized that not killing does not mean killing only healthy people but also people with mental disabilities. Both in the short term, both in the long term. But love them for the sake of Christ, who is also their Savior.

Gen 22:12 explicitly points out that the practice of killing children since the OT times was rejected. When Abraham wanted to offer his son to God and God Himself who forbade not to be killed. Even when the baby Moses was born, Pharaoh ordered to kill the baby Israel but the baby Moses was protected by God. Even when the baby Jesus was born and Herod ordered the babies to be killed in Jerusalem, the angels protected the baby from the vicious killing. So, it is clear that God forbids murder. God defends and protects His people. Even Jesus Christ came to this world for us, sinners who are not worthy of anything, also in the field of decency. Jesus Christ also wants to be a Savior for people with mental disabilities. He was not ashamed to claim they were his brothers (Heb. 2: 11-18; 1 Tim 2: 4).

Suicide is forbidden because a person's life is seen as a gift and belongs to God, only God has the right to take it. So euthanasia is an act that rebels against God (Gen 2: 7).

Indeed the Bible talks a lot about illness. In statistics according to the LAI Bible, the word "sick" contained 919 verses and "sickness" in 104 verses. The details are as follows: blind (81 times), leprosy (59 times), pestilence (54 times), paralysis (27 times), deafness (6 times), tinea versicolor (13 times), fever (11 times), scabies (11 times) ), childless pain (10 times), maternity pain (7 times), bleeding pain (3 times), farsightedness (3 times), epilepsy (2 times), dry cough (2 times), heartburn (1 time), 
inflammation (1 time) 1 time), hunchback

(1 time), water convexity (1 time), dysentery (1 time), intestinal disease (1 time), and lung disease (1 time). However, it does not explain the disease that leads to euthanasia. Even the diseases above which are considered severe such as leprosy, bleeding pain, or paralysis of Jesus succeeded in healing him. So, explain that Jesus is a physician of all illnesses so that if there is severe suffering, say a coma, then the man let himself kill himself how unwise he is. If only he still surrendered to God and God wills, all the illness he suffered would surely be touched and healed by God. The only problem is whether God's plan for our lives is in accordance with the will of man himself. If it is appropriate, surely God will do the same things that are desired by humans, but if God has his own plans then humans cannot force God to cancel His plans.

Bonhoeffer does not agree with euthanasia. He writes:

This is a disturbed life and even though they have to live very unhappy lives, they have to live as human lives. What if a ship would become an epidemic because some people had an infectious disease, and it was impossible to isolate those who were sick, let alone have to kill those who were sick.

Because of that, it is amazing how the writer follows the thoughts of husband and wife,
Kuntadi Sumardikarya, M.Th., pastor of GKI Synod in the West Java Region and Dr. Indriani K. Sumadikarya who believes agrees with the existence of euthanasia. They say:

We need to be more open in cases that have good and serious reasons, for example those who are dying and full of suffering, for whom nothing else can be done. In such a situation, then after praying, purifying motives and considering deeply the benefits (not just profit and loss), then another alternative can be considered the possibility without losing the responsibility of faith in God and legal responsibility to the state.

The author can not understand why the husband and wife came to such a conclusion? Do they not believe that God can do all the miracles to whom Allah Himself wills? Don't they realize that miracles still work today? What else do they link to doing euthanasia but without losing the responsibility of faith in God? This is like thinking that is difficult to accept because what is done by humans, even good deeds, still humans will be responsible for their faith in God. Moreover, actions that rebelled against God, certainly did not escape the court that God did. Here clearly his faith will be held accountable for what they have done. Faith influences someone to do everything

John Keown, Queens' College, 
Cambridge said:

Eutahanasia makes the law bad, ethics becomes radical, inconsistent with the principles of holiness in life. Even the principles set by God have been mocked. Acts of killing that are forbidden by God become permissible by law and doctors. The law changes the rules that have become standard compromise and doctors change the code of ethics into a compromise.

\section{CONCLUSION}

Although almost the last 10 years euthanasia has been practiced in European countries and even parts of the United States, there are still strict pros and cons. Viewed from the aspect of human rights is a moral breakdown that needs to be evaluated again whether euthanasia is in accordance with human rights values because human rights values essentially deny the existence of euthanasia. Also seen from the religious aspect, euthanasia is never justified. Law 6: "Do not kill" can not be laughed anymore means that refusing euthanasia.

God never allowed both the OT and NT to practice euthanasia. So, the faith of Christ is a faith that values human life is a gift and belongs to God. Humans have no right to destroy, except God himself who wants it.

\section{REFERENCES}

1. J.E. Sahetapy and Mardjono Reksodipuro, Parados in Criminology (Surabaya: Center for Criminology Studies at the Faculty of Law, Airlangga University, 1976) 56.

2. Djoko Prakoso \& Djaman Andhi Nirwanto, Euthanasia Human Rights and Criminal Law 63 said in some countries such as the United States, a person who fails to commit suicide can be convicted. Likewise in the state of Israel, attempted suicide is something that is prohibited by law and threatened with crime.

3. Moeljatno, Book of Criminal Law (Yogayakarta: UGM, 1971) 117.

4. Indonesian Medical Ethics Code - annex III (Declaration of Geneva) by the Editorial Committee for the Work of the National Medical Council Consultation (Jakarta: IDI Foundation, 1969).

5. Hud, "Tilly Hutapea's fate depends on Sahetapy?" Jawa Post April 29 (2001) 18, even Java Post April 28 downgraded to cover story stories, then Jawa Post April 29 also reduced the related news.

6. According to the way death occurs, 
science divides it into, as follows: (1) Orthothanasia, i.e. death that occurs due to a natural process. (2) Dysthanasia, i.e. death that occurs unnaturally. (3) Buthanasia, which is a death that occurs with the help or not with the help of a doctor. This third type of death, which the author will discuss, is more popularly called Euthanasia.

7. Dorothy I. Marx, is that right? Bandung: Klam Hidup, t.t.) 80.

8. Ethics The situation rejects the faith that comes first in the Theology Ethics. Situation Ethics denies belief in the existence of God and the absoluteness of the Ten Commandments. Situation Ethics openly rebels against what is called "The Establishment". That is a situation that must not be changed even in the field of church though. Situation ethics moves solely in relativism which originates from Hegel's philosophy and is influenced by the development of the mind in the fields of Psychology, Sociology and Liberal Theology. Situation Ethics views everything not from the viewpoint of the Rule of Truth guided by definite and fixed standards, but in situations and conditions that always change with the standard that all actions must be done for the good and must show the characteristics of love. Thus any action can be justified in the end.

9. Djoko Prakoso \& Djaman Andhi Nirwanto, Euthanasia Human Rights and
Criminal Law 58.

10. The doctor's oath is known as the Hippocratic Oath. Hippocrates, the father of medical science, was a Greek author of medical oaths, which to this day is still the basis of the formulation of the oath of office which is spoken by doctors throughout the world. Hippocrates proposed that doctors always obey and submit to the duties and responsibilities assigned to him. This is intended so that there is no misuse of the doctor's profession for misconduct by a doctor. An example of a doctor's oath in Indonesia, which took effect on 2 June 1960 based on Perpu No. 26/1960, State Gazette of 1960 No. 69, quoted by Ko Tjay Sing, The Secret Work of Doctors and Advocates (Jakarta: Graamedia, 1978) 93, reads as follows:

I swear / promise that: (1) I will devote my life to the benefit of humanity. (2) I will carry out my duties in an honorable and moral manner in accordance with the dignity of my work, a noble tradition of medical office. (3) I will keep everything that I know, because of my work and because of my knowledge as a doctor. (4) The health of suffering will always be my priority. (5) In fulfilling my obligations to sufferers, I will endeavor solemnly that I will not be affected by religious, nationality, ethnicity, party politics or social position. (6) I will give my teachers proper respect 
and expressions of thanks. (7) I will treat my colleagues as siblings. (8) Even if threatened, I do not use my medical knowledge for something that is against the law and humanity. (9) I take this oath / promise seriously and risk my self-respect.

11. Al. Budyapranata pr., Practical Ethics Based on the Ten Commandments (Yogyakarta: Andi, 1987) 31-33. Judging from medical science, euthanasia is used in three meanings, namely: (1) Moving to the afterlife calmly and safely, without suffering, for those who believe in the name of Allah on the lips. (2) Life time will end, alleviated the suffering of the sick, by giving sedatives. (3) End the suffering and life of a sick person intentionally at the request of the patient himself and his family.

12. Kuntadi and Indriani Sumadikarya, "Euthanasia and Incurable Disease and Christian Hope," Guide Vo. 2, No. April 7June (1996) 287.

13. J. Verkuyl, Kapita Selekta Christian Ethics (Jakarta: Gunung Mulia, 1986) 226.

14. Kuntadi and Indriani Sumadikarya, "Euthanasia and Incurable Disease and Christian Hope," 284.

15. R. Jay, The Nazi Doctors: Medical Killing and Psychology of Genocide (London: Papermac, 1986) 95-97; see also Heger, The Men with the Pink Triangle (Boston: Alyson, 1980) 12; also D. Kenrick and G. Puxon, Destiny of Europe Gypsies
(New York: Basic Books, 1972) 72.

16. Read Sinar Harapan, "Artificial Justice in the Context of a World Humk Conference" Monday, September 26, 1977, 8.

17. Djoko Prakoso \& Djaman Andhi Nirwanto, Euthanasia Human Rights and Criminal Law 10.

18. Reuters, "Euthanasia, Finally ...," Kompas April 12 (2001) 3.

19. T.p., "Euthanasia and Medical Practice in the UK," Ethics \& Medicine 9.1. (1993) 11.

20. Ibid.

21. Dorothy I. Marx, Is that OK? 86.

22. Ibid. 89.

23. Reuters, "The Netherlands Legalizes Right to Death," Kompas 12 April (2001) 3. 24. Al. Budyapranata pr., Practical Ethics Based on the Ten Commandments 32 .

25. Bachtiar Surin, Translation and Interpretation of the Qur'an (Bandung: Fa. Sumatra, 1978) 118.

26. Sir Francis Vallat, An Introduction to the Study of Human Rights (London: Europe Publication Limited, 1970) 119. 27. Muladi, "Right to Death," Undip Faculty of Law Weekly Discussion Paper, 8 September (1979) 4.

28. Djoko Prakoso \& Djaman Andhi Nirwanto, Euthanasia Human Rights and Criminal Law 135.

29. Team, Big Indonesian Dictionary 
Journal Kerugma

E-ISSN: 2622-1039

P-ISSN: 2621-8038

(Jakarta: Balai Pustaka, 1989) 99.

30. Law on Human Rights 1999 and Law on

Demonstrations (Bandung: Citra Umbara, 2000) 8 .

31. Yanto M., "Kill or Just Divorce Your Life from a Miserable Body," Koran Tempo 12 April (2001) 7.

32. J. Verkuyl, Capita Selekta Christian Ethics 227.

33. Kuntadi and Indriani Sumadikarya, "Euthanasia and Incurable Disease and Christian Hope," 288. This simple statistic was made possible by Awi Wangidjaya's LogisSoft rocks, the TB and LAI computer programs, which are AF / HarvestSoft products.

34. Bonhoeffer, Ethics (New York: MacMillan, 1972) 166.

35. Kuntadi and Indriani Sumadikarya, "Euthanasia and Incurable Disease and Christian Hope," 299.

36. John Keown, "Courting Euthanasia ?: Tony Bland and the Law Lords," Ethics \& Medicine 9.3 (1993) 37. 